\title{
2 Economic deconcentration in a rational planning system: The Dutch case
}

\author{
Annet Bogaerts, Frans Dieleman, Martin Dijst and Stan Geertman \\ Faculty of Geosciences, Utrecht University, PO Box 80115, 3508 TC, Utrecht, \\ The Netherlands
}

\begin{abstract}
As the epitome of the welfare state, the Netherlands has a long and successful tradition of concentrating urban growth. In this chapter, we analyse how spatial planning policies worked out differently on the spatial economic deconcentration processes in the 1990s for the Northwing of the Randstad and the Breda region. In general terms, it can be stated that no massive employment deconcentration took place in the Netherlands during the 1990s, despite the fact that most employment growth was in the out-of-centre suburban areas. For the near future, it can be questioned whether the decentralization of the power structure in Dutch spatial planning and changing spatial concepts will be as effective as the preceding strategies were in limiting the extensive deconcentration of economic activities
\end{abstract}

Key words: Dutch spatial planning policies, dynamics of economic deconcentration, centralized comprehensive welfare state, Northwing Randstad Holland

\section{1}

\section{Introduction}

The Netherlands has a long and successful tradition of concentrating urban growth. In the course of time, Dutch spatial planners have been inspired by such concepts as 'concentrated deconcentration', 'growth centres', and the 'compact city'; planners have pursued various policies to limit urban sprawl and to optimize land use within the urban landscape. Green buffer areas were created between the central cities and villages to prevent the development of continuous urban areas. New urban developments in the Randstad took place in designated areas encircling the 'Green Heart' of the Randstad, which in this way was conserved as an open agricultural and nature area (Dieleman et al., 1999).

The main reasons for this policy of concentrating urban developments are evident: large numbers of inhabitants in comparison with just a few hectares of space; a general wish to conserve scarce open space and natural environments; higher costs of dispersed spatial developments (infrastructure, for example); and so forth. In fact, the success of relative compact urban developments can be attributed primarily to the Dutch planning system, which is seen by Razin (2000) as the epitome of the welfare state. The model is centralized and characterized by the European Commission (1997, p. 36) as formalistic and rationalistic: "Spatial planning is conducted through a very systematic and formal hierarchy of plans from national to local level, which coordinate public sector activities across different 
sectors." Besides this hierarchical structure, the highly-centralized Dutch fiscal system, the housing policy pursued by the Dutch government, and the influence of local government authorities on local land markets have also facilitated compact urban developments (Dieleman et al., 1999).

Up till now, most studies on concentration/deconcentration in the Netherlands and elsewhere have been devoted to residential functions or built-up areas in general. A reason for this emphasis can be the relatively high impact of residential deconcentration in relation to economic deconcentration: the extensive dispersal of low density residential estates covering large areas in contrast with the concentrated economic developments in outer city places near transport nodes. Another reason for this emphasis on residential deconcentration can be found in the differences in the direct sphere of influence of governmental actions; in most countries, the influence of government authorities on localizing residential units far exceeds their influence on localizing economic activities. In that respect, the free market must not be restrained; moreover, competition between cities or counties in attracting important economic firms does not contribute to the strict implementation of localizing rules.

In this research, however, the emphasis is on the concentration/deconcentration of economic sectors. We distinguish three economic sectors: producer services; retail/consumer services; manufacturing/construction. Producer services consist of transport and car rental firms businesses; retailing/consumer services include retail trade and hotels, but also education and health institutes; and manufacturing/construction includes manufacturing firms, but also electricity and gas utilities. There are three reasons for this selection of economic sectors. First, with a share of two thirds of the total, these sectors dominate Dutch employment. Second, the differences in the locational demands of these sectors make the potential variety in concentration/deconcentration patterns interesting. And third, Dutch spatial policy differs for each of these sectors. The effectiveness of these policies in channelling economic deconcentration have been assessed on the basis of an analysis of their concentration/deconcentration developments in relation to Dutch spatial planning policies. This has been carried out for the recent past and the expected future.

The analysis and discussion in this chapter draw on two urban regions: the Northwing of the Randstad and the Breda region (Figure 2.1). There are several reasons for this choice. The Northwing of the Randstad is the economic heartland of the Netherlands. Not only residential, but also economic developments have concentrated in this region for the past millennium. In contrast, for a long period of time, surrounding regions, such as Breda, enjoyed a much lower economic growth percentage and there was considerable economic commuting into the Randstad. In the last decade or so, there was substantial overspill of residential and economic functions from the Randstad into its surrounding regions, including Breda. Moreover, the spatial structure of the Northwing and Breda regions are quite different: they are polycentric and monocentric respectively. Taken together, these differences and developments through time make comparison of these regions striking. 


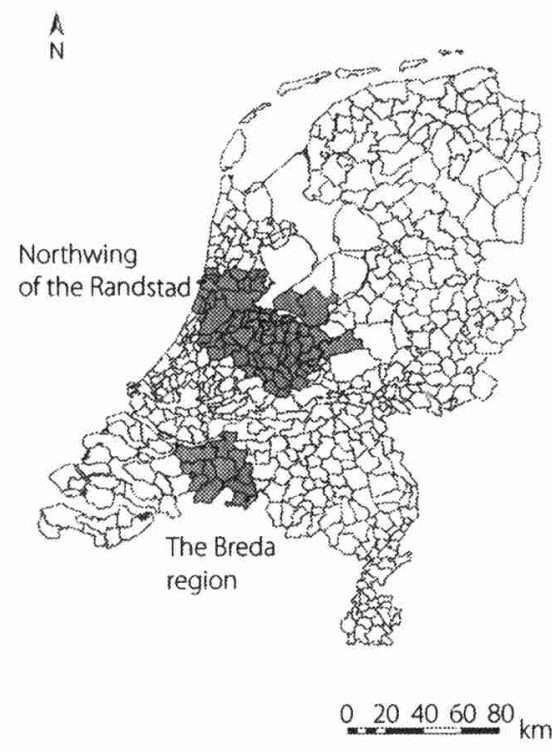

Fig. 2.1 Dutch case studies

On the basis of commuting patterns, the Northwing of the Randstad can be seen as a functional integrated polycentric part of the Randstad (Van der Laan, 1998), which is often considered to be one metropolitan, polycentric urban structure (Davoudi, 2003; Dieleman \& Faludi, 1998). The Northwing is $3,334 \mathrm{~km}^{2}$ in size and accommodates 3.3 million inhabitants, one third of whom are concentrated in the major urban centres of Amsterdam and Utrecht and the mediumsized cities of Haarlem, Amersfoort, and Hilversum. Almere, with approximately 160,000 inhabitants in the year 2002, is the largest new town developed in the past two decades. In the Northwing in the year 2000, 51 percent of the total employment is offered by retailing and consumer services (wholesale and retail trade, leisure facilities, public administration, education and health, social work, and so forth) followed by 34 percent in producer services (transport and distribution, financial services, real estate, and so forth) and 15 percent in manufacturing/construction (manufacturing, electricity, gas, water utilities, and construction). In the Breda region $\left(1,026 \mathrm{~km}^{2}\right), 425,000$ inhabitants are distributed over 11 municipalities, with Breda $(160,000)$ the largest centre. Etten-Leur and Oosterhout are also important centres in this region. Besides retailing/consumer services, which with a share of $\mathbf{5 2}$ percent are significant for regional employment, manufacturing/construction has a share of 26 percent and the second position in the regional labour market.

The central question in this chapter is how Dutch spatial planning policy has influenced economic spatial developments in the last few decades and how policy has worked out differently for the two regions of the Northwing of the Randstad 
and the Breda region. The processes of economic concentration/deconcentration in the $1990 \mathrm{~s}$ are the main point of interest. We start with a brief description of spatial planning policies in the Netherlands as implemented during the past 20 years. This description forms the basis of the analysis of past and ongoing spatial developments. In section 3, the design of the analysis is discussed and some issues concerning data and method are considered. The analytical part of the research is dealt with in two sections. In section 4 , we present our analysis of the developments in the deconcentration of economic sectors for designated urban and suburban zones in the selected regions. In section 5, we pay particular attention to certain dimensions of urban sprawl to describe the economic deconcentration processes in the Northwing and the Breda region. Finally, in section 6 , we put forward our main conclusions and our views concerning future prospects.

\section{2 \\ Dutch spatial planning policies}

For decades, Dutch spatial planning has been based on five principles: the concentration of urbanization, spatial cohesion, spatial diversity, hierarchy, and spatial justice. These principles have received different emphasis in the past and can be linked with a series of Dutch planning concepts such as concentrated deconcentration, compact urbanization, the preservation of 'green areas', and reducing mobility (WRR, 1998; Hajer \& Zonneveld, 2000).

\subsection{1 \\ Concentration of urbanization and the preservation of 'green areas'}

The increasing mobility of people and goods in the 1960s and 1970s reduced the relevance of the direct proximity of urban functions. Moreover, the growing prosperity of a substantial part of the middle-class urban population increased the quest for a living environment that the urban environment could not offer: larger, but affordable houses, with sunlight, in a quiet, safe, green environment. People left the central city to start a new life in suburban communities. In the Second Physical Planning Memorandum (MVRO, 1966), the national government took a strong stand against this suburban sprawl that was threatening to engulf the Green Heart of the Randstad (Faludi \& Van der Valk, 1990, Dieleman et al., 1999). The Memorandum proposed channelling suburbanization into a few towns: the policy of 'concentrated deconcentration'. New urban growth was to be accommodated outside the existing cities in a small number of designated overspill centres referred to as growth centres, similar to the British New Towns. Similar policies have been undertaken elsewhere in Europe, in Sweden and in the Paris region in France, for example (Cervero, 1995). This concentrated deconcentration policy 
was put in force in the late 1970s and early 1980s; it was successful in concentrating suburban residential growth into the selected designated growth centres of Nieuwegein, Almere, Houten, and Huizen in the Northwing of the Randstad, while stemming urban sprawl in the Green Heart (Faludi \& Van der Valk, 1990; Dieleman et al., 1999).

This policy of 'concentrated deconcentration' was brought to an end during the 1980s, because it had a negative impact on population size and employment in central city areas (MVROM, 1988; Dieleman et al., 1999; Hajer \& Zonneveld, 2000). A new policy of 'compact urban growth' was implemented. As formulated in the Fourth Physical Planning Memorandum Extra (VINEX) (MVROM, 1991), this new policy guided urban growth into (re-)development locations within existing cities (brownfield sites) and towards new greenfield sites directly adjacent to the built-up areas of the larger cities. Leidsche Rijn - the greenfield development immediately to the west of Utrecht - is the largest of these VINEX locations; some 35,000 dwellings and 10,000 jobs have been created there (Van der Burg \& Dieleman, 2004).

In addition to this VINEX-policy, the Fourth Physical Planning Memorandum (MVROM, 1988) also introduced a policy for the location of firms: the $A-B-C$ location policy, which could support the concentration of urbanization and the preservation of green areas. This policy was formulated to discourage the use of the private car and promote public transport, cycling and walking in economic commuting. A locations were close to main railway stations; $B$ locations were situated in development nodes outside the larger CBDs and the centres of smaller urban settlements, were reasonably well connected to public transport, and readily accessible by car; $C$ locations had good motorway access - typical examples were business zones in the urban fringe or alongside motorways. The intention of this policy was to guide new employment and public services - especially those attracting many visitors or requiring high levels of employment- towards $\mathrm{A}$ and $\mathrm{B}$ locations. This policy turned out to be difficult to implement and many economic developments took root at 'wrong' locations, in particular at C locations (Schwanen et al., 2004). One important reason appeared to be that local government authorities often gave higher priority to attracting new employment (read: new jobs and income) than to strict adherence to locational rules. It will be apparent that the 'hierarchical and very centralized' Dutch planning system described in the introduction leaves considerable room for local spatial policy initiative and power. Another reason for the unwanted development in C locations was the underestimation of the growth in employment in the office sector during the 1990s that could not be fully accommodated in $A$ and $B$ locations. As a result, the largest employment growth in the 1990 s occurred at C locations. Consequently, the $A-B-C$ location policy has been extensively modified (MVROM, 2001).

Finally, since 1973, Dutch retail policy has beeı highly effective in barring the establishment of out-of-town shopping malls. These were perceived to be a threat to the vitality of town centres and likely to generate extensive private car 
use. Many shops are still located within the built-up areas of cities and towns and within walking or cycling distance for local residents (Evers, 2002). Recently, the national retail planning policy was abolished, since it was blamed for curtailing retail productivity and competitiveness and creating barriers to new firms entering the retail market (Evers, 2002). However, at the local level regulations are still in force preventing the development of out-of-town hypermarkets and shopping malls, although the first signs of the liberalization of this retail locational policy can be found (outlet markets, furniture boulevards, and so forth).

\subsection{2}

\section{Spatial coherence}

While the principles of 'concentrated deconcentration' and 'compact urban growth' relate to the physical aspects of urban activities, the principle of 'spatial coherence' is based on the functional aspects of these activities. Since the publication of the Fourth Physical Planning Memorandum (MVROM, 1988), the Dutch government has encouraged the concentration of related strong economic functions in specific areas readily accessible by main infrastructure (mainports such as Rotterdam harbour and Amsterdam Schiphol Airport, for example). A related functional policy objective that also features in this Memorandum is that of concentrating people's daily activities within the borders of compact daily urban systems (WRR, 1998). This policy promotes the intermingled localization of home, work, and services so as to avoid unnecessary travel movements.

\subsection{3 \\ Spatial differentiation}

The third principle is that of 'spatial differentiation': the preservation and enforcement of diversity within the urban or rural landscape. To prevent areas becoming monotonous, attractive features of Dutch scenery, such as historic sites, would be preserved with robust measures. Rural areas to be preserved include parts of the 'Green Heart' in the centre of the Randstad and the Ecological Main Structure, and natural buffer zones separating cities/villages to prevent the development of continuous built-up areas.

The national government set up an extensive urban renewal program in the same period as the 'compact urban growth' policy. Subsidies were given to upgrade existing housing stock. Unfortunately, the urban renewal policy showed little concern for retaining or attracting employment in the city core areas. This neglect has certainly been one of the main causes of the economic deconcentration processes in the larger Dutch cities. The majority of jobs in many cities can now be found in new employment concentrations outside the original city centres (Schwanen et al., 2004). 


\subsection{4}

\section{Hierarchic urbanization}

The principle of 'hierarchic urbanization' promotes the development/preservation of rank-size within urbanization and a policy to prevent the levelling off of the existing Dutch urban structure. 'Urban nodes' and 'Randstad International' are examples of policy concepts aimed at the development of an urban hierarchy (MVROM, 1988). The first refers to the selection of certain urban nodes in which selective urban policies and governmental finances are concentrated, primarily for reasons of efficiency. The 'Randstad International' policy is intended to concentrate important economic developments in the economic heartland of the Netherlands and make the Randstad an attractive location for international companies (WRR, 1998).

\section{2 .5}

\section{Spatial justice}

The fair distribution of economic activities has always been an important objective of Dutch planning policy. Nowadays, the aim is a fair distribution across the country of growth potential rather than an equal distribution of economic activities. This objective is reflected in the planning concept 'regions on their own strengths', which means that each region should achieve economic growth through its own strengths and make optimal use of its own economic potential (WRR, 1998).

These principles of Dutch spatial planning have successfully guided spatial developments in the last few decades. The question that arises is how these principles influenced economic concentration/deconcentration processes in the 1990s in the Netherlands and how this worked out for the two selected regions: the Northwing of the Randstad and the Breda region. That is the main issue addressed in this chapter. In the next section we first discuss some research-analytical issues.

\section{3}

\section{Data and methodological issues}

To analyse the deconcentration of the economic sectors we have made use of LISA data (Landelijk Informatiesysteem Arbeidsplaatsen [National Information System for the Working Population]) for the years 1991, 1996, and 2000'. Information on the number of employees per economic sector in the study areas is stored in the LISA files. It should be noted, however, that changes in the course of time in the classification and comparative methods necessitated certain adjustments to this dataset before temporal comparisons could be made appropriately.

The employment data have been classified in three economic sectors:

- Retailing/consumer services: wholesale and retail trade, hotels, health institutes, education, household goods, and so forth. 
- Producer services: companies working in finance, business administration, and transport;

- Manufacturing/construction: electricity, gas, and water utilities, construction and manufacturing companies.

We have used two different approaches in our analysis of the spatial deconcentration of economic land use. In this way we were better placed to identify the differentiations in spatial patterns and the underlying spatial processes and investigate them in more depth.

In the first approach, we subdivided the urbanized regions into concentric urban and suburban zones starting from the centre of the central city (monocentric region) or cities (polycentric regions). This subdivision resulted in four functional zones (Figure 2.2):

- $\mathrm{CBD}$ or centre of the central city;

- The rest of the central city;

- Inner suburban ring;

- Outer suburban ring.

These functional zones are based on neighbourhood boundaries, municipal boundaries, and the 'daily urban systems" ${ }^{2}$ ' of the cities (see Van der Laan, 1998). The neighbourhood boundaries are used to define the 'centre' of a central city. In the Northwing of the Randstad a 'centre' can only be distinguished in Amsterdam and Utrecht. The municipal boundaries of the main cities are used to define the

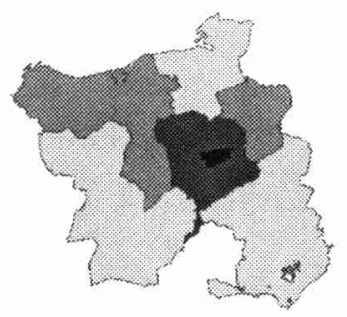

Functional zones

Centre of central city

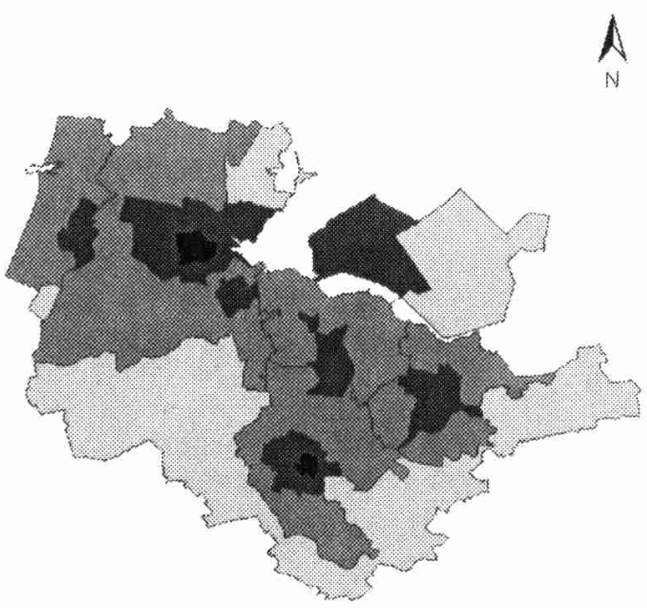

Rest central city (central city)

inner suburban ring

Outer suburban ring

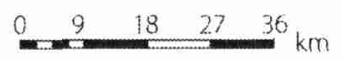

Fig. 2.2 Functional zones in Breda (left) and Northwing (right)

Source: Statistics Netherlands, 2000 
'rest of the central city'. The borders of the daily urban system are used for the definition of the 'inner suburban ring'. In fact, this 'inner suburban ring' is the daily urban system minus the central cities (the centre of the central city and the rest of the central city). The 'outer suburban ring' is based on the relationships of the main cities with the municipalities outside the daily urban system.

The second approach to the analysis of the deconcentration of economic functions follows the work of Galster and colleagues (2001). For residential deconcentration, they developed a conceptual definition of sprawl based on eight dimensions: centrality, density, concentration, continuity, nuclearity, mixed use, clustering, and proximity. They operationalized and tested these dimensions successfully for 13 urbanized areas in USA. For the purpose of our analysis, we selected three of these dimensions:

- Density: The average number of employees per square metre of developable land in an urban area;

- Centrality: The degree to which development in an urban area is situated close to the CBD;

- Mixed use: The degree to which two or more different land uses are intermingled in the same small area and how far this pattern is typical throughout the urban area.

The starting point for this second analysis is a raster of $250 \mathrm{~m}$ by $250 \mathrm{~m}$ superimposed on the study area. Within the raster a distinction is drawn between developable areas such as agricultural land, and other areas such as water, nature, and forests. The calculation of the indices of sprawl is based on the surface area of developable land within the grids. A summary of our calculation and visualization methods for the sprawl indices is given in Bogaerts et al. (2003a).

\section{4 \\ Dynamics in employment distribution over functional zones}

The 1990s are known as a decade of exceptionally strong economic growth in the Netherlands. At 26 percent, the employment growth was well above that of the USA or of European countries as a whole; this growth is attributed to the comparatively advantageous development of labour costs in the 1990s (Atzema \& Van Dijk, 2004). When employment growth in the Northwing of the Randstad is compared with the Netherlands as a whole, it becomes clear that the regional growth was stronger than in the rest of the country. Between 1991 and 2000, the number of jobs increased by 36 percent. With a growth of 104 percent, the producer services account for a large share of the new employment. In the Breda region, at 30 percent the employment growth is slightly higher than the Dutch average, but less than that of the Northwing. This difference can be envisioned as a clear identification of the different economic positions of the two regions within the Dutch economic 
situation. In the Breda region, the enormous growth in producer services also stands out ( 64 percent). In both regions the retailing/consumer sector also increased substantially, although less than the producer services (32 percent in the Northwing and 37 percent in the Breda region). Manufacturing/construction hardly increased in either the Northwing ( 0.7 percent) or in the Breda region ( 7 percent).

Against this background of general trends in employment growth, in this section we present our analysis of the different functional zones of the Northwing and Breda region in the development of employment for the period 1991-2000. We centre our discussion on (1) the growth of employment in each zone and (2) the changes in the share in employment of each functional zone. In addition to total employment, we have analysed the dynamics for the three identified sectors: retailing/consumer, producer services, and manufacturing/construction.

Figure 2.3 shows that, in the period 1991 to 2000 , employment increased substantially in both regions, particularly in the zones outside the centres of the central cities. So the rest of the central cities, especially the suburban zones, enjoyed a substantial growth rate. This increase in employment was largely caused by the expansion of the producer services in the Northwing of the Randstad and the Breda region. However, the growth rates of these regions differ substantially: while in the Northwing the inner and to a lesser extent the outer suburban ring show the biggest growth rates, within the Breda region the highest growth rate in producer services employment can be found in the rest of the central city and to a lesser extent in the suburban zones. The difference in the scale of developments between the regions is clear to see. Moreover, the outcome of the policy of compact urban growth is clearly illustrated in this development. With regard to retailing/consumer services, development growth was more or less equal in all other functional zones outside the city centres, both within the Northwing and the Breda region. The manufacturing/construction sector shows a slight overall increase in employment in both regions, with the exception of the centres of the central cities in the Northwing of the Randstad, where employment in this sector has decreased substantially.

In general terms, this uneven employment development between the centres of the central cities on the one hand and the rest of the central cities and suburban zones on the other can probably be attributed to the intense competition for space in these areas, the consequent high rents, and restricted expansion potential. Obviously, firms with a high demand for extensive floor space such as transport or car rental firms or business administration have moved to out-of-town-centre locations. In addition to this competition for space, the urban renewal policy referred to above showed little interest in attracting or even retaining employment in the centres of the central cities. In fact, this policy was focused on residential and social upgrading rather than economic upgrading. This preference may well have contributed to the uneven employment development spread.

These trends are reflected in the development in employment share of each functional zone as illustrated in Table 2.1. In general terms, it can be seen that, although in an absolute sense employment levels within the centres of the central cities increased rather than decreased, in a relative sense the share decreased in 


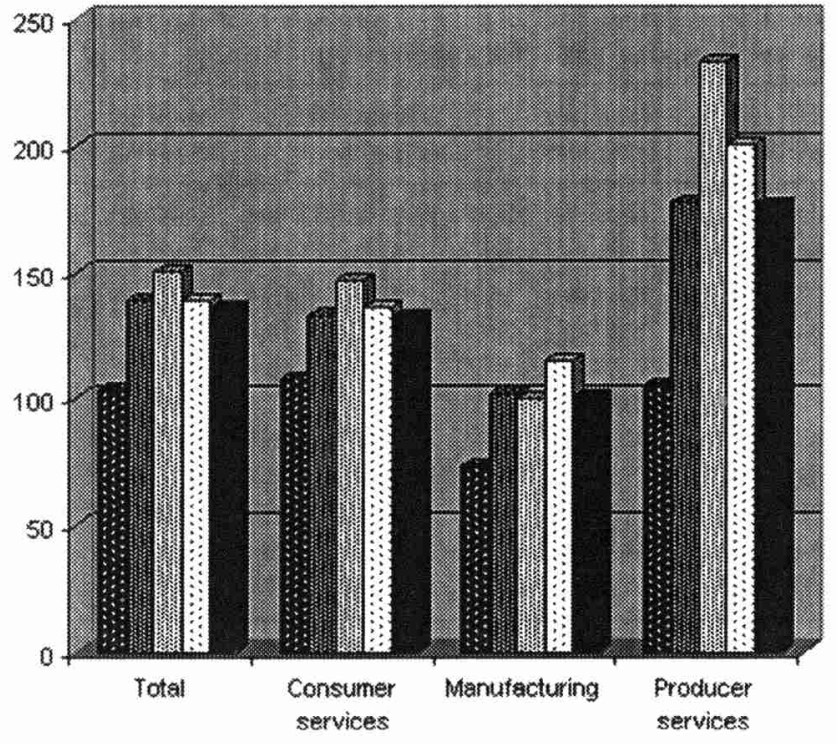

- Centre central city

west central city

由inner suburban

couter suburban

- Total

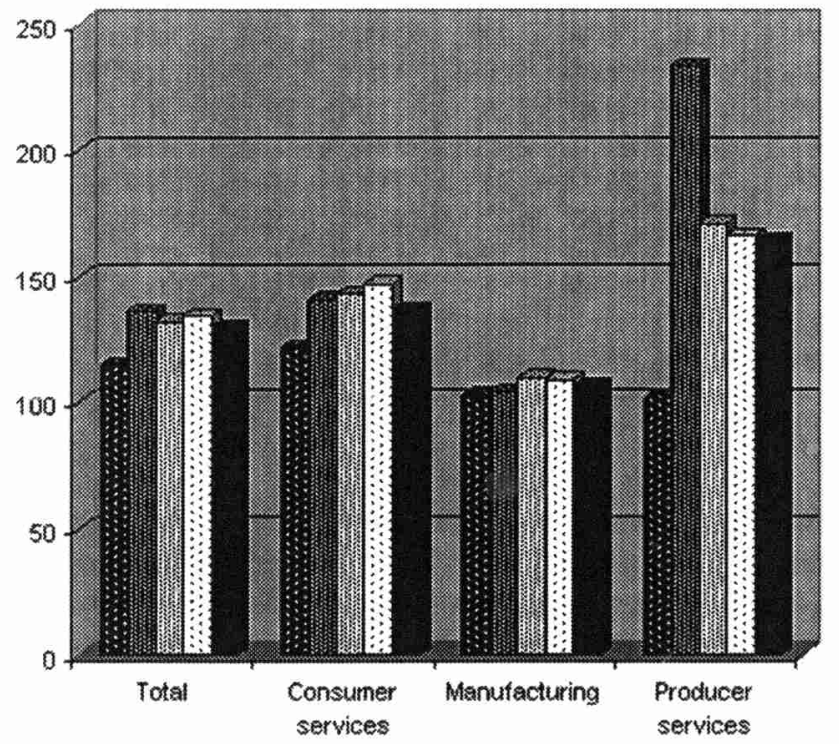

- Centre central city

a Rest central city

ตinner suburban

a Outer suburban

- Total

Fig. 2.3 Development in employment for functional zones in the Northwing (above) and Breda regions (below) 1991-2000 $(1991=100)$

Source: LISA 1991-2000 
Table 2.1 Total employment and development in share of employment of each functional zone: Northwing (above) and Breda region (below) 1991-2000 (percent)

\begin{tabular}{|c|c|c|c|c|c|c|c|c|c|}
\hline & & \multicolumn{2}{|c|}{$\begin{array}{l}\text { Total } \\
\text { employment }\end{array}$} & \multicolumn{2}{|l|}{$\begin{array}{l}\text { Retailing/ } \\
\text { consumer }\end{array}$} & \multicolumn{2}{|c|}{$\begin{array}{l}\text { Manufacturing/ } \\
\text { construction }\end{array}$} & \multicolumn{2}{|l|}{$\begin{array}{l}\text { Producer } \\
\text { services }\end{array}$} \\
\hline & & Absolute & Share & Absolute & Share & Absolute & Share & Absolute & Share \\
\hline \multirow{10}{*}{$\begin{array}{l}\text { Centre of } \\
\text { central city } \\
\text { Rest } \\
\text { central city } \\
\text { Inner } \\
\text { suburban ring } \\
\text { Outer } \\
\text { suburban ring } \\
\text { Total } \\
\text { urbanised area }\end{array}$} & 1991 & 239988 & 19.4 & 133682 & 20.7 & 19431 & 7.6 & 85485 & 26.7 \\
\hline & 2000 & 248276 & 14.8 & 143786 & 16.8 & 14255 & 5.6 & 89983 & 15.9 \\
\hline & 1991 & 422342 & 34.2 & 228020 & 35.4 & 77552 & 30.4 & 114467 & 35.8 \\
\hline & 2000 & 586690 & 34.9 & 302940 & 35.5 & 79237 & 30.9 & 203392 & 36.0 \\
\hline & 1991 & 430785 & 34.8 & 206268 & 32.0 & 120174 & 47.1 & 95176 & 29.8 \\
\hline & 2000 & 647347 & 38.5 & 301966 & 35.4 & 119752 & 46.7 & 221861 & 39.3 \\
\hline & 1991 & 143426 & 11.6 & 76812 & 11.9 & 37718 & 14.8 & 24448 & 7.6 \\
\hline & 2000 & 198785 & 11.8 & 104650 & 12.3 & 43356 & 16.9 & 48949 & 8.7 \\
\hline & 1991 & 1236541 & 100 & 644782 & 100 & 254875 & 100 & 319576 & 100 \\
\hline & 2000 & 1681098 & 100 & 853342 & 100 & 256600 & 100 & 564185 & 100 \\
\hline & & \multicolumn{2}{|c|}{$\begin{array}{l}\text { Total } \\
\text { employment }\end{array}$} & \multicolumn{2}{|l|}{$\begin{array}{l}\text { Retailing/ } \\
\text { consumer }\end{array}$} & \multicolumn{2}{|c|}{$\begin{array}{l}\text { Manufacturing/ } \\
\text { construction }\end{array}$} & \multicolumn{2}{|l|}{$\begin{array}{l}\text { Producer } \\
\text { services }\end{array}$} \\
\hline & & Absolute & Share & Absolute & Share & Absolute & Share & Absolute & Share \\
\hline \multirow{6}{*}{$\begin{array}{l}\text { Centre of } \\
\text { central city } \\
\text { Rest } \\
\text { central city } \\
\text { Inner } \\
\text { suburban ring }\end{array}$} & 1991 & 32261 & 22.4 & 21124 & 29.7 & 3654 & 8.1 & 7426 & 30.7 \\
\hline & 2000 & 37050 & 19.8 & 25689 & 26.4 & 3756 & 7.8 & 7588 & 19.1 \\
\hline & 1991 & 39295 & 27.2 & 18647 & 26.3 & 12719 & 28.2 & 5901 & 24.4 \\
\hline & 2000 & 53538 & 28.6 & 26331 & 27.1 & 13242 & 27.4 & 13750 & 34 \\
\hline & 1991 & 41724 & 28.9 & 17212 & 24.2 & 17410 & 38.6 & 6585 & 27.2 \\
\hline & 2000 & 55175 & 29.5 & 24587 & 25.3 & 19101 & 39.5 & 11232 & 28.3 \\
\hline Outer & 1991 & 30916 & 21.4 & 14034 & 19.8 & 11319 & 25.1 & 4278 & 17.7 \\
\hline suburban ring & 2000 & 41385 & 22.1 & 20613 & 21.2 & 12282 & 25.4 & 7112 & 17.9 \\
\hline Total & 1991 & 144196 & 100 & 71017 & 100 & 45102 & 100 & 24190 & 100 \\
\hline urbanised area & 2000 & 187148 & 100 & 97220 & 100 & 48381 & 100 & 39682 & 100 \\
\hline
\end{tabular}

Source: LISA 1991-2000

favour of all the out-of-centre functional zones in both the Northwing and the Breda region. In the Northwing in particular, the inner suburban zone attracted a substantial share of this suburbanization process. However, despite this overall suburbanization trend, about 50 percent of all employment has remained within the boundaries of the central cities. For instance, for the producer services sector, 52 percent and 54 percent respectively is still situated in the cities of the Northwing and Breda region. From this observation it can be concluded that, within this sector, a clear differentiation has taken place; some parts still consider the central city to be a valuable location, even economically speaking, despite the competition for space and high rents, while others have found suitable locations in the suburban zones. This upcoming of new suburban office space can be encountered along outof-town main highways and around suburban railway/metro stations; some quite extensive office areas were constructed during the 1990s (Amsterdam South East, for example). 
On the basis of these analyses, one can conclude that, during the 1990s, employment growth took place primarily within the rest of the central cities and the suburban zones, although the centres of the central cities preserved their employment levels in an absolute sense. This statement holds for both the Northwing and Breda region and for all the sectors listed, with the exception of manufacturing in the centre of the central cities in the Northwing of the Randstad; employment growth decreased there substantially in both absolute and relative terms. Moreover, the substantial overall growth rates of the producer services sector surpassed all other employment developments, although consumer sector employment also increased markedly. In conclusion, although no massive deconcentration took place in the 1990s in the sense of a substantial moving out of employment from city centres to suburban locations, the suburban growth rates far exceeded those of the cities. Taken together, the Dutch planning principles of 'concentration', 'spatial coherence', and 'spatial differentiation' seem to have limited the extent and the territory over which economic functions have deconcentrated.

\section{5}

\section{Dimensions of employment deconcentration}

In the previous section, the deconcentration processes for designated urban and suburban zones of the Northwing and the Breda region were analysed. This section describes a more detailed analysis obtained by making use of the level of employment sprawl indices (see Galster et al., 2001; Bogaerts et al., 2003b). The emphasis is on three sprawl indices: density, centrality, and mixed use. A raster of $250 \mathrm{~m}$ by $250 \mathrm{~m}$ is superimposed on the study area and a distinction is drawn between developable areas (agricultural land) and non-developable areas (water, nature, and forests). The calculations of the sprawl indices are based on the developable areas.

\subsection{1}

\section{Density}

Density is probably one of the most frequently used measures to capture urban development patterns. Density can be defined as the average number of employees (or the surface area of economic land use) per hectare of developable land in the urban area. The level of density is calculated by counting the number of employees per 250 by 250 metre raster and dividing this number by the developable surface within this raster.

Figure 2.4 shows the development in total employment density for the Northwing. In general, the centres of the cities have by far the highest employment densities; the density decreases with distance from the centre. Looking at the development in employment density, there appears overall to have been a substantial increase in employment density, which has taken place primarily as an extension and intensification of existing employment concentrations. For the few developments taking place at new locations, the infrastructure appears to have been 


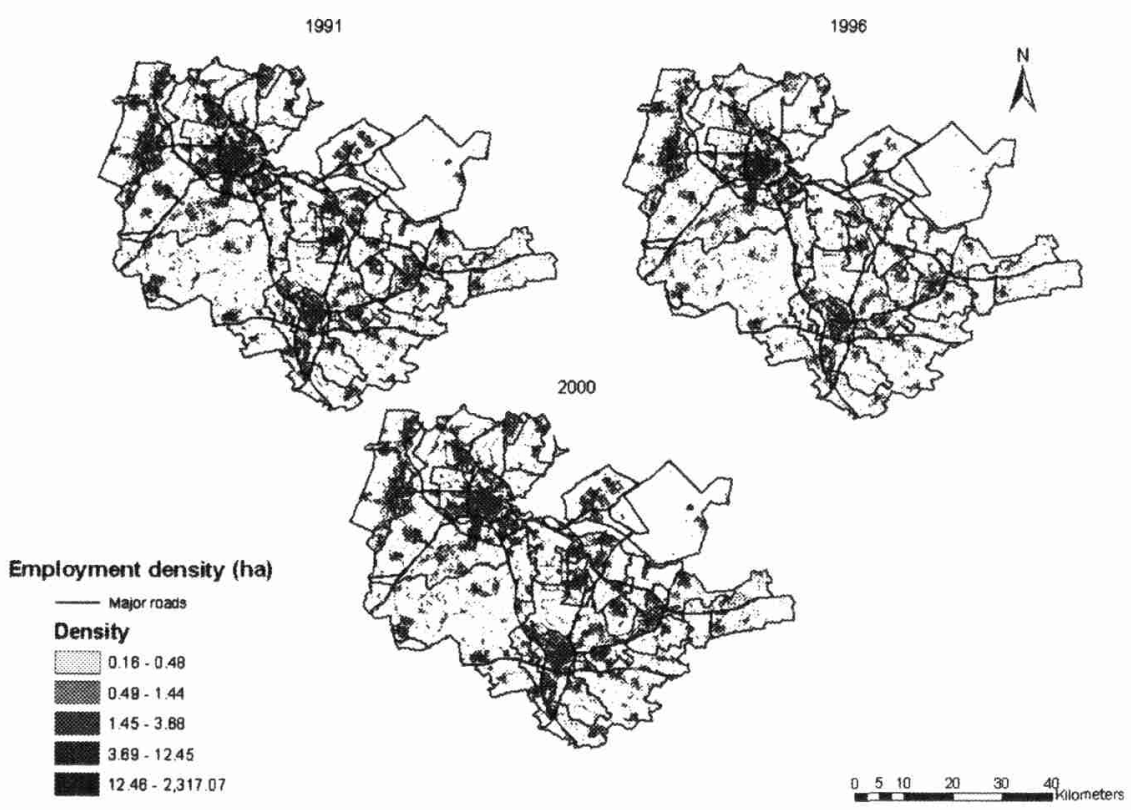

Fig. 2.4 Level of total employment density in the Northwing of the Randstad, 1991-1996-2000 Source: LISA 1991-1996-2000

a conductor for these, so that new employment developments take place along highway networks.

This picture for the Northwing corresponds largely with that of the much smaller Breda region. There, the highest employment densities can be found in the central cities of Breda and the surrounding municipalities of Etten-Leur and Oosterhout. Again, employment density decreases as distance from the city centres increases. As in the Northwing, the development of employment densities between 1991 and 2000 primarily took place in the form of extensions and intensifications of existing employment centres. New employment developed on just a few areas in an East-West band within the Breda region; there again, the infrastructure was an important stimulator. Local and regional spatial policies also contributed to these new East-West developments through the active stimulation of links to Roosendaal in the West and Tilburg in the East.

Differentiating these general trends in employment density for the sectors identified makes some differences clear. Retailing/consumer services are highly concentrated in the city centres and their increase in employment density can mainly be found at or adjacent to existing locations. This preservation and extension of existing spatial pattern is expected to be a consequence of the strict national retail policy, mentioned above as part of the urban concentration policy of the 1990s, which prohibited the development of huge out-of-town shopping centres and hypermarkets far away from the cities. The exceptions to this rule can be 
seen in the outskirts of the central cities and consist primarily of Do-It-Yourself stores and retailers in furniture and domestic decoration. The growth of this kind of suburban-located retailing/consumer services employment concentrations is, however, quite substantial. As a result, despite the fact that no huge distant out-of-town shopping malls were constructed in the Dutch case study areas during the 1990s, some suburban growth took place in this sector on a more modest scale and distance.

Producer services and their development took place not only in the city centres, but also at the edge of central cities and in suburban locations. This statement applies to both the Northwing of the Randstad and the Breda region. Moreover, the layout of the suburban developments is concentrated: subcentres alongside infrastructure nodes or in smaller towns such as IJsselstein and Mijdrecht. These developments can be contrasted with economic spatial developments elsewhere, where they take the form of extensive widely-spread developments (in USA, for example). This clustering in the Netherlands can be attributed to the planning principles of 'concentration' and 'spatial coherence' referred to above.

Employment concentration and development in the manufacturing/construction sector spread around the area of the central cities and along main roads and motorways on the outskirts of central cities and within suburban locations. This is the case for both the Northwing and the Breda region.

On the basis of these density figures, one can state that the density of employment increased primarily as an extension and intensification of existing employment concentrations. Moreover, infrastructure can be considered a conductor for new developments, since many new developments are concentrated alongside highway networks. One cannot conclude from the employment density figures that a massive process of economic deconcentration took place within the Dutch context, at least not in a massive, dispersed fashion. No large-scale urban sprawl of employment operating at the expense of the cities can therefore be identified. On the contrary, one must conclude that the existing employment locations strengthened their position. Employment densities increased not only in city centres (retailing/consumer services), but also in suburban locations (producer service sector). In the figures concerning our next measure, 'centrality', the picture becomes clearer. Moreover, the density figures show that even suburban development took place primarily as an extension and intensification of existing employment concentrations, also in the form of concentrated/clustered development. This concentration can be attributed to a considerable extent to the Dutch policy of the concentration of urbanization and the preservation of 'green areas'.

\section{5 .2}

\section{Centrality}

'Centrality' indicates the degree to which employment (or economic land use) is located close to the centres of cities and towns. A loss or centrality is often seen as a reference to increasing sprawl within, and in the proximity of, an urban area. The level of centrality is measured by calculating the average distance of employment 
from the city centre. Concentric circles one kilometre apart are drawn from the city centre outwards. The Northwing has a polynuclear structure with several centres, so the centrality is measured for each of these separately. To visualize centrality, the employment density is calculated and shown for each kilometre ring. Note that the centrality measure takes the mean density value of a ring and so does not permit the identification of concentrations in one or more directions within that ring.

Figure 2.5 shows the level of total employment centrality in the Northwing. The employment density is shown in that zone.

In Figure 2.5, two zones can be seen where the employment density is relatively high: the centre of the city, and the surrounding suburban municipalities. In the area between these two zones the employment density is relatively low. This picture applies in general terms to both the Northwing and the Breda region; Amsterdam and Utrecht show a more gradual overall decrease of employment density from the city centre. Moreover, the location of this intermediate zone is much closer to the city centre in the Breda region than it is in the Northwing, probably as a result of the difference in scale (the small size of the city of Breda in comparison with the Northwing). These buffer zones between towns reflect the 'spatial differentiation' principle of Dutch planning policy. The intermediate zones of relatively low density could be the result of this policy.

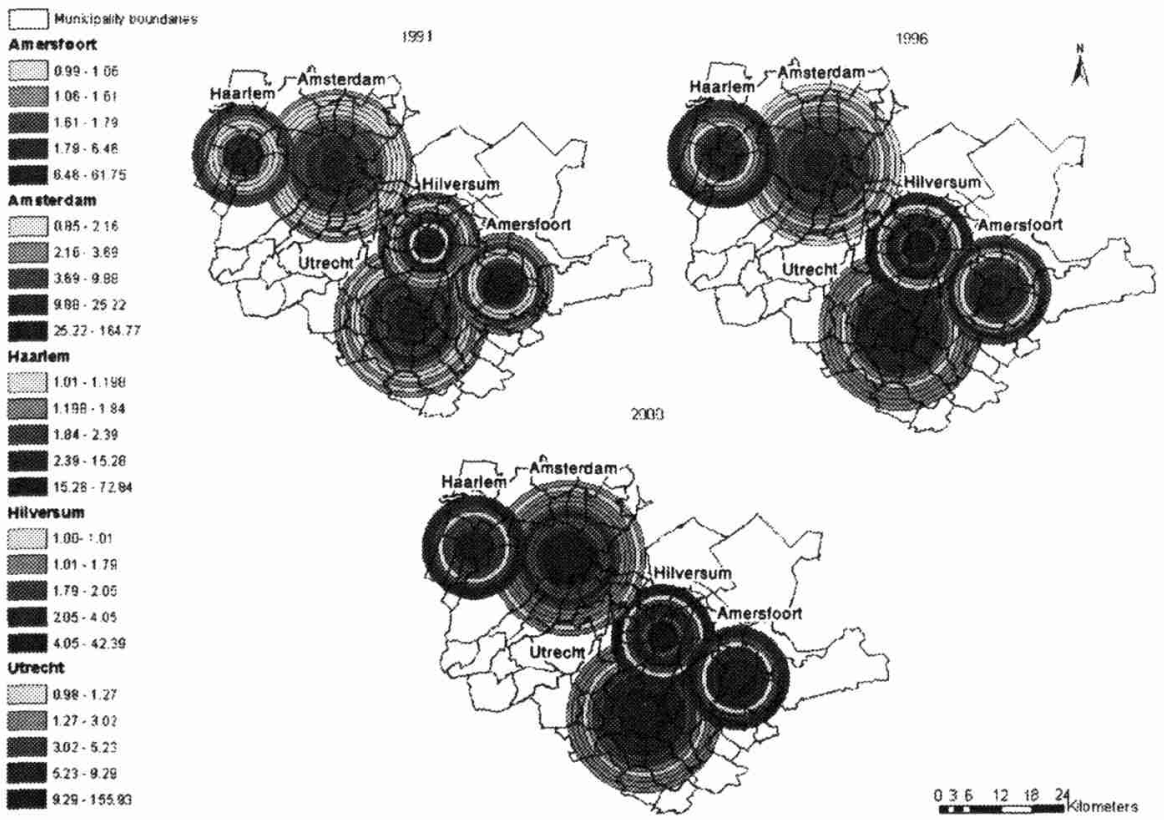

Fig. 2.5 Level of total employment centrality in the Northwing region, 1991-1996-2000

Source: LISA, 1991-1996-2000 
The overall development of centrality between 1991 and 2000 shows a clear picture: in the surrounding municipalities, the growth of the level of employment density exceeded the growth in the town centres. As a consequence, centrality decreased between 1991 and 2000, although the city centres remain important areas of employment concentration, as previous density discussion makes clear Moreover, the centrality figures and maps show that in the $1990 \mathrm{~s}$, although the intermediate 'lower' density zones remained vibrant, they declined in magnitude. As a consequence, the density differences between the zones levelled out and overall the centrality decreased during the 1990s.

In contrast with the other two economic sectors, the overall level of centrality for manufacturing/construction is quite low. This is in line with the extensive space needs of most firms in this sector and the increasing competition for space and subsequent high costs in the town centres.

On the basis of these centrality figures, one can state in general terms that centrality has decreased for all the economic sectors within both case study areas. This is primarily the result of the substantial employment developments during the 1990s, particularly in the suburban zones. These developments can be attributed to the increasing competition for space in the town centres and probably also to the Dutch policies of 'spatial differentiation' and 'A-B-C location policy' (see section 2).

\subsection{3}

\section{Mixed use}

The 'mixed use' indicator measures the degree to which two or more different land uses coexist (Galster et al., 2001, p. 995). The level of 'mixed use' in an area is determined by measuring the average employment density there and comparing it with the population density.

Figure 2.6 shows the level of mixed use in the Northwing of the Randstad. The areas with the highest level of mixed use of employment - defined here as a combination of employment and population, thus a mix of working and living are found mainly in the town centres. The areas with a low level of mixed use (mono-functional areas) can be found in the city centres as well as in the outskirts and more suburban regions. The level of mixed use of employment decreases with distance from the centre of the city. Moreover, mixed use increases in the course of time, a development that is visible in both the Northwing and in the Breda region. The 'spatial coherence' principle of Dutch planning is clearly reflected in the resulting development patterns (see section 2). It is argued that one of the principles of Dutch planning is the formation and encouragement of compact daily urban systems, thereby avoiding unnecessary commuting.

The analysis of the level of mixed use of employment for the different economic sectors allows the following observations to be made. Similar pictures of mixed use are shown for both the Breda region and the Northwing of the Randstad. For retailing/consumer services, the level of mixed use is high in comparison with the 


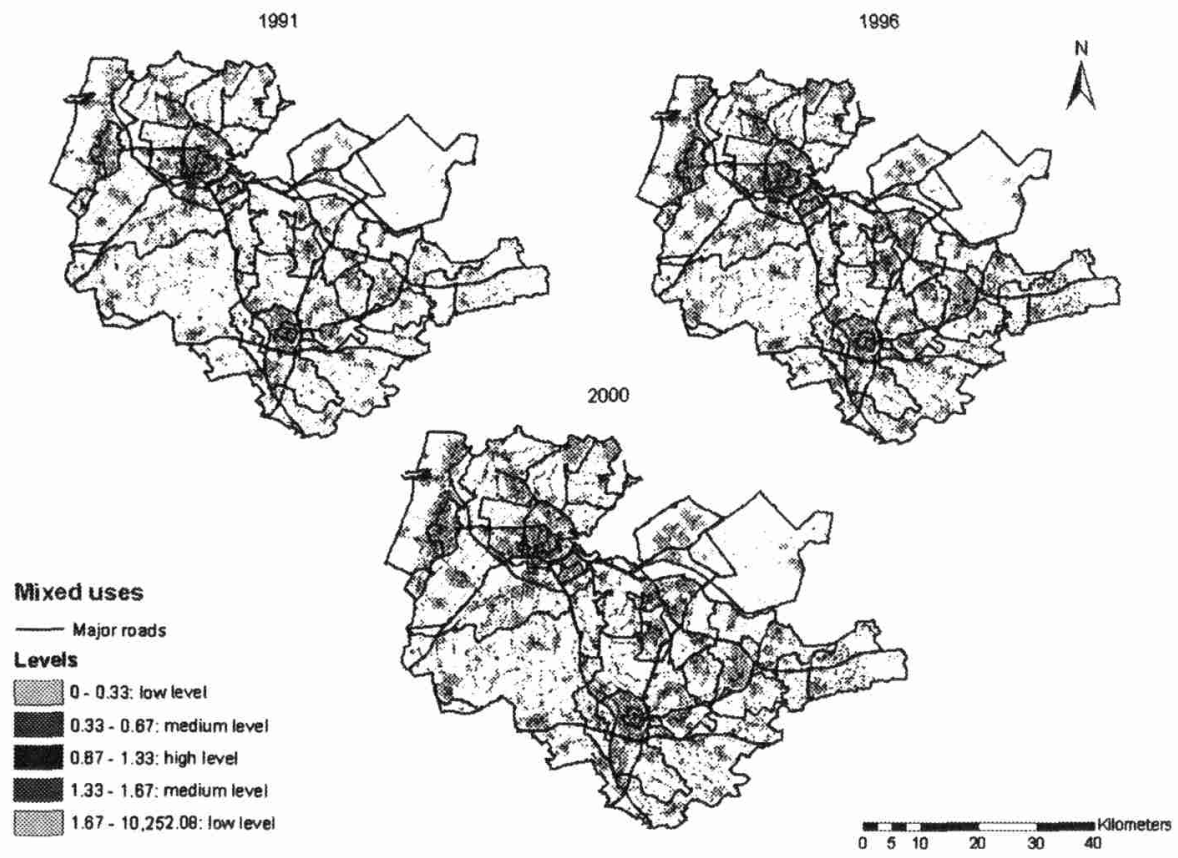

Fig. 2.6 Level of mixed uses in the Northwing of the Randstad, 1991-1996-2000 Source: LISA 1991-1996-2000 and KWB Statistics Netherlands, 1994-1997-200I

other sectors; moreover, the level increased between 1991 and 2000. At the same time, areas of mono-functional retailing/consumer employment are developing in the outskirts of the towns. Without doubt, this differential development - highlymixed consumer services in the centres; low mix of consumer services in the outskirts - parallels the quite extreme diversification within this sector: from small specialized retail shops and hairdressers to supermarkets, large shops for furniture, hospitals, and public transport companies. The firms needing extensive space within this sector are more likely to be located at the outskirts of towns. Intermingling these kinds of economic function with residential functions was not an explicit spatial policy. In contrast, in the centres of Dutch towns the intermingling of living and working (in shops, for example) has long been the spatial policy, in particular for reasons of security and liveability (see below).

For producer services, the picture of mixed use is similar to that for retailing/consumer services: high levels of mixed use in the city centres; lower levels in the outskirts and suburban locations. However, areas of mono-functional employment of producer services can also be found in the city centres of the largest cities.

The level of mixed use in the manufacturing/construction sector appears to be significantly lower than the level in the other sectors, which is as expected from the characteristics of this sector: extensive need for space; nuisance from noise, and 
so forth. Moreover, and in agreement with these characteristics, the level of mixed use decreased between 1991 and 2000 and the development of mono-functional employment in manufacturing/construction is moving away from the town centres.

Reasons can be found for these differential developments in mixed use in the various Dutch spatial policies. First, in all the large Dutch municipalities, the local government authority has encouraged the return of the residential function in the city centres for reasons of liveability, security, and so forth. So, the traditional leisure shopping centres of Dutch cities became more mixed during the 1990s, partly because once again apartments were built above shops. This spatial policy has been made explicit and its positive effects are shown in the figures presented. Second, the Dutch policy of 'hierarchic urbanization' has also influenced the city centres. As indicated in sections 1 and 2, retail policy in particular has embraced and preserved the notion of the 'hierarchy of centres', in which the centres of the central cities continued to be the location for the most specialized shops and firms with the entire city as its consumer market, while the suburban locations became host to the facilities and services at the neighbourhood level. One of the consequences of this policy has been the preservation and even reinforcement of the city centre as a central and sustainable shopping area (consumer services). This policy has also contributed to mixed use in the city centres. Third, given the pressure on the Dutch land market and the related high prices per square metre, especially in the city centres, there is a tendency for spatial differential selection: services and firms needing a small area and with a high dependency on visitors passing by can be found in the centres of the towns; services and firms needing an extensive area and with less dependency on passing visitors seek cheaper and larger locations at the outskirts of the cities. The outcome of these large-scale developments with low mixed use at the outskirts of the towns is mono-functionality. This feature can also be seen as an exemplification of the Dutch policy of the "concentration of urbanization' (see section 2). Fourth, during the 1990s almost all medium-sized and large cities in the Netherlands undertook the restructuring of the areas within the city centres in the vicinity of the central railway stations (brownfield locations). Luxury apartments to re-introduce high income groups into the city centres and mono-functional office areas of producer services can be found there (financial services, lawyers, government institutions, and so forth This restructuring could be the reason for the centrally-located mono-functional areas of producer services. In fact, the central localization of these producer services can be considered a minor success of the much criticized ABC-location policy, since these services are often visitor-intensive and situated near railway stations (see section 2).

\section{6}

\section{Conclusions and discussion}

In this chapter, we have analysed the concentration and deconcentration processes of three economic sectors in the 1990s for the case study areas of the Northwing of the Randstad and the Breda region, and assessed the impact of five planning 
principles of the Dutch planning system. In this concluding section we discuss these issues and the anticipated effectiveness of the Dutch planning system in the near future.

In general terms, it can be stated that employment growth usually takes place within suburban zones, although the centres of the central cities have preserved their employment magnitude in an absolute sense during this period. This process can be observed in the monocentric Breda region on a modest scale, and on a more extensive scale in the polycentric Northwing of the Randstad. Moreover, this growth pattern appears to apply to all three identified sectors, although the substantial growth rates of the producer services sector in the outer centres areas outweigh all other employment developments. As a consequence of these multifocal developments, the centrality within the Breda region and the Northwing of the Randstad decreased between 1991 and 2000, although the cities of Amsterdam and Utrecht form the exception to this general rule since both centres preserved their centrality. At the same time it should be noted that, in terms of employment growth, there were no large-scale out-of-town developments located far from the central cities: the increase of employment density took place primarily as extensions and intensifications of existing employment concentrations. Moreover, it appears that, particularly for new economic developments, highways and to a lesser extent railway stations form the prime conductor for the new developments: new employment, especially in producer services, developed in clusters along the main infrastructure and on infrastructure nodes. Retailing/consumer services clearly followed developments in population densities, preserving their position primarily in the city centres and growing in shopping centres located within suburban communities. The more distant out-of-town shopping centres (shopping malls) so familiar in other countries hardly exist in the Netherlands, except for some dedicated categories such as Do-It-Yourself stores and large retailers in furniture and domestic decoration or outlet shops. These firms needing extensive floor space have found much cheaper locations at the outskirts of the central cities, where accessibility by car is the main criterion. Manufacturing/construction can usually be found spread around the central cities area and alongside the main roads and highways in the outskirts of central cities and in designated areas in more suburban locations. This generalization applies to both the Northwing and the Breda region.

So, in short, on the basis of the above, one has to conclude that no massive deconcentration took place in the Netherlands during the 1990s, despite the fact that most employment growth was in the out-of-centre areas. It seems that the 'concentration of urbanization', 'spatial coherence' and 'spatial differentiation' principles of Dutch spatial planning policy limited both the one-sided direction and the magnitude by which economic functions were deconcentrated.

The 'concentration' principle effectively limited the dispersed sprawl of economic functions over the total metropolitan area, since even suburban deconcentrated development took place in quite a concentrated manner along highways, at infrastructure nodes, and on designated sites. Question marks can, however, 
be set against claims for the effectiveness of this policy, in particular the A-B-C location policy. Its central purpose was to concentrate employment and visitorintensive firms near public transport nodes. From the empirical analysis it appears that much of the new economic development took place close to main roads and highways. It can be seriously questioned whether all these firms can be characterized as employment- or visitor-extensive. However, the speed of the developments played an important part in the mismatch between policy and reality. Moreover, many firms were not overly disappointed when they found that they did have to establish themselves on $\mathrm{C}$ locations. In contrast with $\mathrm{C}$ locations, $\mathrm{A}$ and $\mathrm{B}$ locations were characterized by high land prices, poor accessibility by car, and no or very expensive parking lots.

The 'spatial coherence' principle provided a mixed picture in the 1990s. The city centres retained and even increased their high degree of mixture, a situation which can be attributed to the explicit policy of stimulating living in city centres, in particular above department stores (retailing/consumer services) and offices (producer services). This policy of mixing working and residential functions can be justified as a means of preserving/improving the liveability of city centres and from security considerations. Moreover, the policy contributes to a reduction in commuting movements. The level of mixed use decreases with distance from the city centre. The development of mono-functional employment areas has taken place in particular in the outskirts of the towns, although a few areas of mono-functionality can also be found in the centres of the bigger cities. The restricted appearance of mono-functional areas can be attributed to different spatial policies, for example: preventing nuisance arising from mutually conflicting functions (parking, noise, smell); concentrating similar functions together spatially for efficiency (infrastructure costs).

The effectiveness of the 'spatial differentiation' principle is reflected in particular on the outskirts of the towns. Economic developments have taken place there in a concentrated manner rather than spreading over whole metropolitan areas. Outer areas have been preserved from the negative consequences of dispersed economic development, including nuisance and superfluous traffic movements. Clear examples of these preservation and differentiation policies can still be found at the outskirts of the city of Breda and the surrounding municipalities of the medium-sized cities of Haarlem and Hilversum in the Northwing. Urbanization pressure on these areas is growing enormously, however, and the green buffer zones between the urbanized areas are being filled in. This process will doubtless lead eventually to one monotonous built-up area.

The principles of 'hierarchic urbanization' and 'spatial justice' are much harder to recognize in the empirical material investigated in this study. What has become clear, however, is that, although in relative terms growth in employment in the Northwing of the Randstad is comparable with that of the Breda region (36 percent and 30 percent respectively), in absolute terms they are of a different order of magnitude (see Table 2.2). The policy principle of 'hierarchic urbanization' will no doubt persist. 
Table 2.2 Population growth and employment growth within the central cities of both study areas, 1991-2000 (percent)

\begin{tabular}{|c|c|c|c|c|}
\hline & \multicolumn{2}{|l|}{ Population } & \multicolumn{2}{|l|}{ Employment } \\
\hline & Absolute, 2000 & $\begin{array}{l}\text { Development } \\
\text { 1991-2000 } \\
\text { (index) }\end{array}$ & Absolute, 2000 & $\begin{array}{l}\text { Development } \\
\text { 1991-2000 } \\
\text { (index) }\end{array}$ \\
\hline \multicolumn{5}{|l|}{ Northwing } \\
\hline Amsterdam* & 874,053 & 112 & 483,137 & 130 \\
\hline Utrecht & 233,667 & 101 & 180,535 & 120 \\
\hline Haarlem & 148,484 & 99 & 64,311 & 101 \\
\hline Amersfoort & 126,143 & 124 & 64,209 & 135 \\
\hline Hilversum & 82,177 & 97 & 42,774 & 152 \\
\hline \multicolumn{5}{|l|}{ Breda region } \\
\hline Breda & 160,615 & 106 & 90,588 & 127 \\
\hline
\end{tabular}

*Note that in this research Almere is part of the Amsterdam central city area.

Source: LISA 1991-2000, Statistics Netherlands- Statline.

This assessment of the effectiveness of the Dutch planning principles in guiding the spatial development of the various economic sectors brings us to a consideration of the future prospects of Dutch spatial planning policy. Spatial planning has recently changed substantially. One change is that, until recently, the national government had most directive power in spatial planning. This power structure will now change so that a substantial part of the national power will move to the regional level, and the provinces are expected to coordinate communication and decision making processes with the wide range of parties involved (municipalities, provinces, water institutions, important private and public stakeholders, and so forth). This decentralization will doubtless result in tailor-made solutions capable of dealing with the inevitable spatial conflicts that will arise between the participants involved.

Some fundamental changes in Dutch spatial planning policy concern the placing of people's activities within the boundaries of daily urban systems, the principle of 'spatial coherence', and the introduction of the new concept of a Network Society (MVROM, 2004). In the recently published Memorandum Nota Ruimte (National Spatial Strategy) the emphasis on the compact growth of isolated cities has made way for the new concept of the 'Network Society', in line with the principles of 'hierarchic urbanization' and 'spatial justice'. Towns and cities are no longer envisioned as separate entities, but interconnected and forming 'networks on different hierarchical scales' (Hajer \& Zonneveld, 2000; Healey, 2004). The underlying idea is the interrelationship between separate towns (mutual dependency) and the consequent need for cooperation and mutual adjustment (specialization). The internal economic specialization of centres/towns in a network is expected to increase flows between centres/towns within the network and consequently the interaction between them. Moreover, the growth in importance of connections opens the 
potential for new developments at new locations, such as infill locations between interconnected urbanized areas (Hajer \& Zonneveld, 2000).

Taking the two considerations together, we have to place serious doubts against the capability of the current policy, which up till now has been effective, of preventing large-scale deconcentration of economic development far beyond the boundaries of existing cities. Decentralized powers and changing spatial concepts will change the planning process and the content of spatial decision-making and finally the resulting outcomes. There will probably be large-scale spatial deconcentration of appropriate economic activities such as producer or manufacturing/construction services or large-scale retailing/consumer services in the form of malls. Some such 'outlets' have already appeared on the Dutch landscape. The familiar concepts of 'edgeless city' (Lang \& LeFurgy, 2003) or even 'urban field' will then come into the picture.

\section{Notes}

\footnotetext{
${ }^{1}$ We were able to make use of LISA data within the Selma project thanks to our project partner RIVM.

${ }^{2}$ The 'daily urban system (stadsgewest)' can be described as a structure of one or more large cities and surrounding smaller cities/municipalities that are 'combined' in a functional relationship of mutual relationships (Zonneveld, 1991, p. 224).
}

\section{References}

Atzema O, van Dijk J (2004) The persistence of regional unemployment in the Netherlands. Utrecht University, Utrecht

Bogaerts A, Dieleman FM, Dijst M, Geertman S (2003a) Case study analysis: technical report. URU, Utrecht University, Utrecht

Bogaerts A, Dieleman FM, Dijst M, Geertman S (2003b) Case study analysis the Netherlands: work package 1 SELMA program. URU, Utrecht University /MNP, RIVM, Utrecht/Bilthoven

van der Burg A, Dieleman FM (2004) Dutch urbanization policies: from 'compact city' to 'urban network'. Tijdschrift voor economische en sociale geografie 95(1):108-116

Cervero R (1995) Planned communities, self-containment and commuting: a cross-national perspective. Urban Studies 32(7):1135-1161

Davoudi S (2003) Polycentricity in European spatial planning: from an analytical tool to a normative agenda. Eur Plann Stud 1(8):979-999

Dieleman FM, Faludi A (1998) Polynucleated metropolitan regions in Northwest Europe: theme of the spatial issue. Eur Plann Stud 6(4):365-377

Dieleman FM, Dijst M, Spit TJM (1999) Planning the compact city; the Randstad Holland Experience. Eur Plann Stud 7(5):605-621

European Commission (1997) The EU compendium of spatial planning systems and policies. Luxembourg: Office for Official Publications of the European Communities. (Regional Development Studies 28)

Evers D (2002) The rise (and fall?) of national retail planning. Tijdschrift voor economische en sociale geografie $93(1): 107-113$ 
Faludi A, van der Valk A (1990) Rule and order: Dutch planning doctrine in the Twentieth century. Kluwer, Dordrecht

Galster G, Hanson R, Ratcliffe MR, Wolman H, Coleman S, Freihage J (2001) Wrestling sprawl to the ground: defining and measuring an elusive concept. Housing Policy Debate 12(4):681-717

Hajer M, Zonneveld W (2000) Spatial planning in the network society - rethinking the principles of planning in the Netherlands. European Planning Studies 8(3):337-355

Healey $\mathrm{P}(2004)$ The treatment of space and place in the new strategic spatial planning in Europe. International Journal of Urban and Regional Research 28(1):45-67

van der Laan L (1998) Changing urban systems: an empirical analysis at two spatial levels. Regional Studies 32:235-247

Lang RE, LeFurgy J (2003) Edgeless cities: examining the noncentered metropolis. Housing Policy Debate 14(3):427-460

MVRO (1966) Second physical planning memorandum. Ministry of Housing and Physical Planning, The Hague

MVROM (1988) Fourth spatial planning memorandum. Ministry of Housing, Physical Planning and the Environment, The Hague

MVROM (1991) Fourth spatial planning memorandum extra. Ministry of Housing, Physical Planning and the Environment, The Hague

MVROM (2001) Fifth spatial planning memorandum 2000/2020. Ministry of Housing, Physical Planning and the Environment, The Hague

MVROM (2004) Spatial Memorandum: space for development. Cabinet Council The Hague

Razin E (2000) The impact of local government organization on development and disparities: a comparative perspective. Environ Plann C: Gov Policy 18:17-31

Schwanen T, Dijst M, Dieleman FM (2004) Poiicies for urban form and travel: The Netherlands experience. Urban Studies 41(3):579-603

Wetenschappelijke Raad voor het Regeringsbeleid (WRR) (1998) Ruimtelijke Ontwikkelingspolitiek. SDU uitgevers, The Hague (Rapporten aan de Regering nr. 53)

Zonneveld W (1991) Conceptvorming in ruimtelijke planning: encyclopedie van planconcepten. Planologisch Demografisch Instituut van de Universiteit van Amsterdam, Amsterdam 